\title{
THE FORMATION OF INNOVATIVE ECONOMY OF UKRAINE IN THE CONTEXT OF EUROPEAN UNION ASSOCIATION AGREEMENT
}

\author{
Tetiana Bulakh¹, *Olena Lytvyn², Oksana Ivashchenko ${ }^{3}$, Natalia Grynchak ${ }^{4}$ \\ ${ }^{1}$ PhD, Associate Professor, National Academy of Statistics, Accounting and Audit, \\ 1 Pidhirna Ave, Kyiv, Ukraine, E-mail address rla799@ukr.net \\ ${ }^{2}$ PhD, Associate Professor, Banking University, Andriivska Str., 1, Kyiv, Ukraine, \\ E-mail address alling@ukr.net \\ ${ }^{3}$ PhD, Associate Professor, National Academy of Statistics, Accounting and Audit, \\ 1 Pidhirna Ave, Kyiv, Ukraine, E-mail address oi2013@ukr.net \\ ${ }^{4}$ Seniour lecturer, National Academy of Statistics, Accounting and Audit, \\ 1 Pidhirna Ave, Kyiv, Ukraine, E-mail address gnatalia@ukr.net
}

Received 2019-06-03; Accepted 2020-02-04

\begin{abstract}
This study is devoted to the problem of the formation of Ukraine's innovative economy in the context of a European Union Association Agreement. The main objective of the article is to study the consequences of signing of Association Agreements between Ukraine and the EU, to identify the benefits and problems, and to propose promising directions of such cooperation in the context of the formation of the innovative economy of Ukraine. The research methodology is based on a foreign and Ukrainian scientific literature and statistical data analysis (within the last five years) to show collaboration between the EU and Ukraine. The priority directions of such collaboration areas are such as: the introduction of all-embracing implementation strategy, sponsorship system's creation of Ukrainian exports to the EU, a stimulation of development of innovations within the framework of realization of the international programs, introduction of certification norms and standardization of products in Ukraine and others. The results of the study can be useful for scholars, ministries, institutions that are engaged in this range of issues.
\end{abstract}

Keywords: Association Agreement, European Union, European integration, economy, custom tariff adjusting, quota, standardization.

JEL Codes: F15; F12; O11

\section{Introduction}

The innovative way of the development is one of the possible directions of ensuring competitiveness of the country's economy. Ukraine needs a sustainable growth of the economy to improve the well-being of people with a help of European integration. On June 27, 2014 Ukraine became a full-fledged associate member of the EU. In accordance with the provisions of the Agreements, Ukraine and the EU identified such key priorities as: a constitutional reform, judicial and law enforcement systems, an electoral law, anti-corruption, public administration, economy and taxation, which are the most important issues for reforming in Ukraine.

Ukraine has carried out the implementation of planned measures in these areas for the last five years. The results have been reported annually by the Cabinet of Ministers and the National Council for Reforms. The ambiguous reaction of Ukrainian society has been concerned with the implementation of reforms. The transformation of the economy according to the Agreements, specification of further work in foreign economic relations and the economic complex itself require a scientific understanding of the situation and the development of applied measures (Harbovs'ka, 2017). Ukrainian experts say that the Treaty is only filled with content and summing up is too early. Otherwise, there are problems and perspectives of the innovative economy's formation of Ukraine at the same time in the context of approaching to the EU's political and economic standards.

Copyright (C) 2020. Published by Vytautas Magnus University. This is an open access article distributed under the terms of the Creative Commons Attribution Non Commercial 4.0 (CC BY-NC 4.0) license, which permits unrestricted use, distribution, and reproduction in any medium provided the original author and source are credited. The material cannot be used for commercial purposes. 
The scientific problem of this article lays upon the question of a scarce and insufficient attention of domestic science, revealing the perspectives of the formation of Ukraine's innovative economy in the context of the Association Agreement with the EU. In addition, there are no clear criteria for determining the strategic directions of Ukraine's integration into the European space and concrete measures for stabilizing the country's economy and increasing its export potential. The above situation introduces new requirements to continue the research of the foreign trade activity's tendencies of Ukraine and certain branches of its economy within the framework of interaction with the EU.

The hypothesis of the paper is based on a complex view to the issue, concerning the formation of Ukraine's innovative economy in the context of a European Union Association Agreement.

The purpose of the article is to study the consequences of signing of Association Agreements between Ukraine and the EU, to identify the benefits and problems, and to propose promising directions of such cooperation in the context of the formation of the innovative economy of Ukraine.

The object is the process of the formation of Ukraine's innovation economy in the context of the Association Agreement with the EU.

The subject is the relations between Ukraine and the EU in the context of the implementation of the terms of the Association Agreement.

The research methods are based on a foreign and Ukrainian scientific literature and statistical data analysis within the last five years to show collaboration between the EU and Ukraine.

The practical implication is the results that can be useful for scholars, ministries, institutions that are engaged in this range of issues.

\section{Literature analysis}

Many studies and scientific papers of leading research institutes and scholars are dedicated to the determination of problems, prospects and consequences from the implementation of the Association Agreement between Ukraine and the EU. The evaluation of modern research publications makes it possible to distinguish four basic directions of scientific views in the field of relations between Ukraine and the European Union (Fig. 1).

1. The investigation of foreign trade activity of Ukraine including the issues of relations with EU countries in the context of the European integration intentions of the country (there are studies of Bulakh et al. (2018; 2019), Lytvyn (2016), Poshedin and Chulaievska (2017), Wolczuk (2009), etc.).

2. The assessment and study of the Association Agreement between Ukraine and the EU and its impact on the country's economy (there are studies of Harbovs'ka (2017), Heyets' and Shynkaruk (2014), Manaienko and Putilina (2017), Potter (2017), Vinokurov et al. (2016), Vošta et al. (2016), etc.).

3. The disclosure of the issues of foreign trade relations with individual EU member states in the context of the Association Agreement (there are studies of Maksak et al. (2017), Raboshuk and Shymanska (2016), Yarosh-Dmytrenko (2017), Yatsenko et al. (2017) and others).

4. The assessment of the problems and prospects of certain sectors of the economy of Ukraine in the context of the foreign trade activity's intensification with the European Union (there are scientific papers of Butyter and Wachowska (2015), Buryak (2017), Chauffour et al. (2011), Nekhay et al. (2011), O. Lutskiv (nd), etc.). 


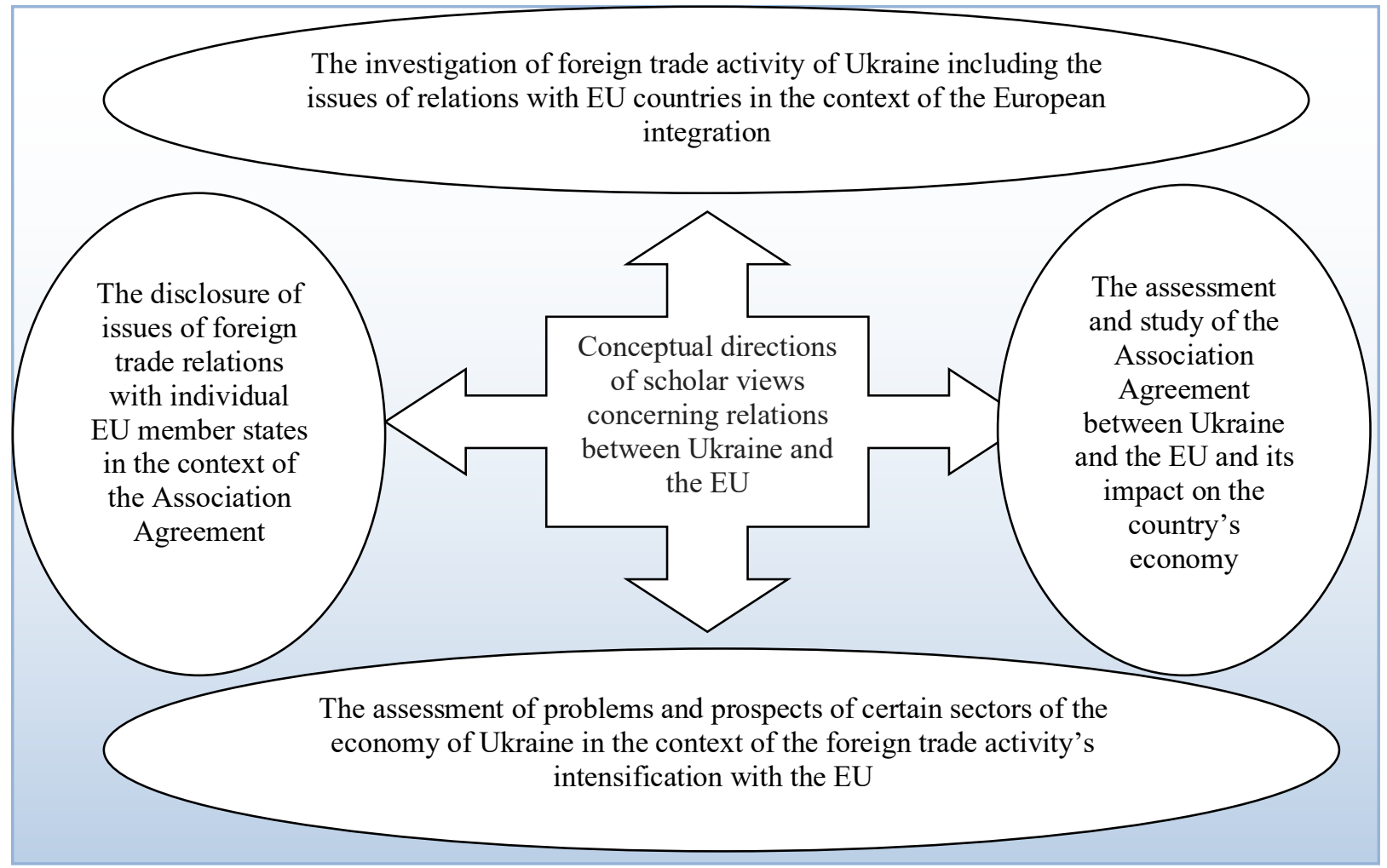

Fig. 1. Conceptual Directions of Scholar Views Concerning Relations between Ukraine and the EU

Sources: compiled by the authors

Despite the sholars, the paper has determined a complex view of the issue, concerning the formation of Ukraine's innovative economy in the context of a European Union Association Agreement. It has been found the consequences of signing of Association Agreements between Ukraine and the EU, to identify the benefits and problems, and to propose promising directions of such cooperation in the context of the formation of the innovative economy of Ukraine.

\section{Methodology}

The research methodology is based on a foreign and Ukrainian scientific literature and statistical data analysis within the last five years to show collaboration between the EU and Ukraine. The main statistical methods are used in data analysis: descriptive statistics, which summarize data from a sample using indexes, such as the mean or standard deviation, and inferential statistics, which draw conclusions from data that are subject to random variation. Statistical methods involved in carrying out a study include planning, designing, collecting data, analysing, drawing meaningful interpretation and reporting of the research findings.

It is determined that the priority directions of the collaboration between the EU and Ukraine are such as: the introduction of all-embracing implementation strategy; sponsorship system's creation of Ukrainian exports to the EU; a start of functioning of Export Credit Agencies; mechanisms for the increase of efficiency and transparency of custom registration and other procedures in the custom control; a stimulation of development of innovations within the framework of realization of the international programs; the increase of national producers' support, bringing exporters from non-EU countries, placing production capacities on the territory of Ukraine with the further prospects of products' supply to the European markets; introduction of certification norms and standardization of products in Ukraine. 
It is found that the necessity of forming a healthy competitive environment in the direction of effective promotion of the domestic producer has been proved by developing and implementing effective cost regulators at the macro level. It is proved the necessity of developing a long-term strategy for Ukraine's economic developments while taking into account the main stages and deadlines of implementing the DCFTA.

It is shown that even despite the pressure from Russia's side and EU's high dependence on energy import from Russia, the EU has demonstrated its wiliness to support Ukraine in stabilizing its economy, encouraging judicial, political and economic reforms and further economic integration with the EU. However, turbulent and unpredictable political situation in Ukraine has negatively affected the cooperation between Ukraine and the EU. Ukraine's trade performance and signing DCFTA with the EU has been influenced by the war conflict with Russia. It caused not only economic slowdown, falling commodity prices, high inflation, but also negatively affected Ukraine's innovation development due to worsening investment climate in the country.

\section{Results and discussion}

The European integration choice of the Ukrainians is the most important achievement of Ukraine in recent years that is possible due to the Revolution of Goodwill. The processes of European integration influence the reforms in our country that make bringing the Ukrainian legal acts in line with the requirements of the European Union.

Integration processes with the EU are not only new economic prospects for Ukraine but also an opportunity to overcome the technological gap between Ukraine and the EU, the development of a new system of public administration and economic management, and the construction of a truly legal state, based on transparent mechanisms for using budget funds and respect for Human Rights (Rudik, 2014).

In addition, Ukraine has received the following benefits:

1. An access to the European market. The European Union is the only largest market in the world, which consists of 28 countries and has the population 11 times more compared to Ukraine. There are over 500 million consumers with average revenue of USD 39.000 per year (Heyets', Shynkaruk, 2014).

2. The establishment of a free trade area with EU countries. It doesn't only reduce tariff and non-tariff barriers among the countries but positively affects the increase of FDI volumes from the EU to Ukraine. The experience of Central and Eastern European countries that have joined the FTA with EU countries shows an increase in direct investment inflows compared to the previous period. On average, the share of FDI in the GDP of these countries three years before and three years after signing of the FTA was: in Bulgaria - $0.6 \%$ compared to $2.1 \%$ respectively, the Czech Republic $1.8 \%$ vs. $2.9 \%$, Estonia $-4.3 \%$ vs. $7.5 \%$, Hungary $-4.8 \%$ vs. $7.0 \%$, Lithuania $-2.1 \%$ vs. $5.3 \%$, Poland $-1.0 \%$ vs. $2.4 \%$, Romania - 0,6\% vs. $1.7 \%$, and Slovakia - $1.5 \%$ compared to $5.3 \%$ (Eurostat, 2017).

3. The reduction of import duty rates for Ukrainian goods. It should be noted that the process of mutual markets' opening was asymmetric (Table 1). Customs duties for $94.7 \%$ of tariff lines of industrial production and $82.2 \%$ of tariff lines of agricultural products were immediately abolished from the EU side, while Ukraine has only introduced a preferential regime for $49.2 \%$ of the total product range. Correspondingly, there were changes and proportions in the level of tariff protection between the parties. The average arithmetic import duty on European products in Ukraine decreased from $4.95 \%$ to $2.42 \%$, whereas from the EU side - from $7.6 \%$ to $0.5 \%$. After the end of the 10-year transition period, Ukraine can retain residual import duty levels for $8.7 \%$ of agricultural products, which will eventually give it somewhat higher level of tariff protection (Zovnishnoekonomichni ..., (n.d.)). 
According to exports under the free trade regime with the EU (zero or reduced customs duties), it is necessary to obtain a certificate for EUR.1 for goods' transportation that is issued by the customs authorities of Ukraine from 1 January 2016.

The procedure for issuing EUR.1 certificates is like the procedures in the European countries. It provides maximum simplification of certificates' issuance on a royalty-free basis within the shortest possible time. It simultaneously strengthens the exporter's responsibility of the information reliability to determine the Ukrainian origin of goods (Uhoda..., (n.d.)).

Table 1. Dynamics of Liberalization of Foreign Trade between Ukraine and the EU in Accordance with the DCFTA (Zovnishnoekonomichni..., (n.d.))

\begin{tabular}{|c|c|c|c|c|c|c|}
\hline \multirow{2}{*}{ Commodity groups } & \multicolumn{4}{|c|}{ Average arithmetic import duty rates, \% } \\
\hline & \multicolumn{2}{|c|}{$\begin{array}{c}\text { Basic rates } \\
\text { (before the } \\
\text { Agreement) }\end{array}$} & $\begin{array}{c}\text { Basic rates } \\
\text { (after the Agreement, } \\
\text { 2016) }\end{array}$ & $\begin{array}{c}\text { Basic rates } \\
\text { (after 10-year transitional } \\
\text { period, 2026) }\end{array}$ \\
\hline & Ukraine & EU & Ukraine & EU & Ukraine & EU \\
\hline Entire product range & 4,95 & 7,6 & 2,42 & 0,5 & 0,32 & 0,05 \\
\hline $\begin{array}{c}\text { Agricultural products } \\
\text { (H5 01-24 Groups) }\end{array}$ & 9,24 & 19,8 & 6,77 & 0,6 & 1,38 & 0,24 \\
\hline $\begin{array}{c}\text { Industrial goods } \\
\text { (HБ 25-97 Groups) }\end{array}$ & 3,67 & 3,9 & 1,12 & 0,5 & 0,00 & 0,00 \\
\hline
\end{tabular}

According to the State Fiscal Service (DFS), 100.000 certificates for EUR.1 were issued to Ukrainian goods during 2016-2017 for the purpose of their transporting to the EU that indicated an increase in exports to the EU.

The largest number of certificates was issued to Poland - 28957 units, or 29\%, Germany 13643 units, (13\%), Romania - 8042 units, (8\%), to Italy - 5319 units, (5\%), the Netherlands 4159 units, Lithuania - 3903 units, and Bulgaria - 3348 units (State fiscal service, 2017).

The export volumes are also assisted by import duties that have already been abolished for most goods in the EU. As the result, the average rate for Ukrainian exports to the EU has decreased from $7.6 \%$ to $0.5 \%$. Thus, most of duties were canceled in April 2014 in the autonomous trade preferences for Ukraine.

Nowadays it is possible to sell live animals, fish, cheese, nuts, most fruit, vegetables and oilseeds, confectionery, light industry goods, mechanical engineering, etc. (Sibekina, 2018).

1. An access to the public procurement in EU countries. The harmonization of legislation and procedures in the field of public procurement will enable Ukrainian enterprises to participate on an equal basis with European enterprises in government procurement, service provision and tendering at the EU, national and regional levels. The volume of this market is almost USD 2.5 trillion.

2. An access to the markets of non-EU countries. It will be ensured via the harmonization of technical regulations and standards in accordance with the requirements of the EU and the transition to globally acceptable standards via the mutual recognition agreements with the EU. It will also provide prospects for the recognition of relevant Ukrainian goods in the US markets, Japan, Canada and Korea (Heiler, Pyatnyts'kyy, 2013).

3. An approximation of the legislative base and administrative procedures of Ukraine to the relevant EU norms and procedures. According to the strategy of European integration of Ukraine, the adaptation of Ukrainian legislation to EU legislation is bringing national legislation closer to the modern European system of law, which will ensure the development of political, entrepreneurial, social and cultural activity of Ukrainian citizens, economic development of the state within the EU, 
and promote gradual growth of living standards population. The implementation of the provisions of the European legislation, provided for by the economic part of the Association Agreements, is extremely important in the context of reforms. The provisions of the agreement can also serve as the basis for a new model of socio-economic development of Ukraine. Therefore, developing the concept and programs of sectoral economic reforms, it is necessary to take immediately into account the requirements of the basic EU directives, harmonization of which is provided by the Agreements.

4. The opening of new markets for investment, in particular the ability to attract direct investment in priority sectors of the economy with cheap but highly skilled labour and raw materials. According to the forecasts of the International Center for Policy Studies (Avramchenko et al., 2013), The FDI from the EU countries will focus on seven of the most attractive types of economic activity in Ukraine, such as: pharmaceutical production, wholesale and retail trade, trade in vehicles, production of fats, production of other food products, beverage production, tobacco industry, textile industry and tailoring, real estate operations and information activities (Buryak, 2017).

5. The establishment of close cooperation among donor countries and recipient countries of direct investment. In addition, the free trade area increases the level of competition, which positively affects the development of business environment in the regions of Ukraine.

6. A free movement of capital related to the provision of loans dealing with commercial operations or the provision of services, as well as financial loans and investor loans. They are related to trading or the provision of services, as well as financial and investor loans. It expands the opportunities for obtaining European loans by industrial enterprises in each region (Buryak, 2017).

7. Expanding the range of partners and diversifying supplies to reduce the risks in case of non-access to the CIS markets.

8. A possibility of obtaining technical and financial assistance from the EU, which is possible due to both direct investments from the EU countries and simplification of access to quality import equipment and equipment. It is for the domestic industry, which is characterized by high energy intensity due to its predominance in the structure of low-tech enterprises with an outdated material and technical base and low technological adaptability, not so much of technological matters as the feasibility of their implementation. Therefore, if the new terms of trade within the EU provide a relative reduction in the price of technological lines and equipment supplied by the producers of the EU member states, it will have a positive effect on updating the material and technical base of industries for which equipment in Ukraine is not produced (Lutskiv, (n.d.)).

9. The preservation of sovereignty in the implementation of foreign economic policy, etc.

10. At the same time, it is worth implicating rather incomplete adaptability of Ukrainian small and medium-size businesses to the EU market conditions due to the lack of an integrated strategy of a state regulation of the foreign trade sector in the conditions of European integration. There is still a lack of regulation of export lending, a culture of doing business in foreign markets, the export development, an adaptation of Ukrainian legislation to European requirements and so on.

The main problems of foreign trade relations between Ukraine and the European Union within the framework of the Association Agreements are:

1. An asymmetry in the supply of goods. Ukraine exports low-margin goods, mainly raw materials and semi-finished goods. The EU countries import high-margin finished goods to the country. Thus, a number of export-oriented sectors of the domestic economy cannot develop, which leads to preservation of export opportunities and reduction of the state's export potential (YaroshDmitrenko, 2017).

2. Significant costs of compliance with EU standards. Adapting to the requirements of the quality and safety of products provided by technical barriers to trade (TBT) and sanitary and phytosanitary measures is a complex, lengthy and costly process that blocks an access to European markets for most potential Ukrainian suppliers. For example, the output of domestic poultry 
producers on the EU market has lasted for five years. As a result, despite the rendered duty-free tariff quotas, the European market for dairy products, lamb, pork and beef remains de facto closed to Ukrainian producers. During 3.5 years of these quotas (starting in April 2014), exports have not started to the EU by the above-mentioned product groups (Zovnishnoekonomichni..., (n.d.)).

3. Quotas supply of key export products. In particular, the EU has tariff quotas for 36 groups of agricultural commodity products and import duty rates are still at the barrier level. The volume of tariff quotas for 18 goods is already envisaged within five years from the date of application of the trade provisions of the Agreement. For example, the Association Agreement provides a gradual increase in the volumes of the tariff quota for grape and apple juices from 10.000 tons / year to 20.000 tons / year over five years. In 2017 the volume of the quota is 12.000 tons / year, in $2018-$ 14.000 tons / year, in 2019 - 16.000 tons / year, in 2020 - 18.000 tons / year, in 2021 and then annually -20.000 tons / year (Sibekina, 2018).

It is interesting to note that quotas for honey, grape and apple juices, processed tomatoes, sugar, barley groats and flour, poultry, wheat, corn, and barley are mostly used by Ukrainian exporters.

An administration of tariff quotas is carried out in accordance with two principles: «first came, first served» and through the system of import licenses (Ministry of economic development and trade of Ukraine, 2017).

It should be noted that the raw material orientation of the Ukrainian economy in the conditions to overcome, the restriction on exports of agricultural raw materials in the form of tariff quotas does not constitute a strategic obstacle to the development of its trade and economic relations with the EU countries. It clearly hinders the achievement of the short-term goals of reorientation of domestic producers from lost markets on the territory of the Eurasian Economic Union (EAEU).

4. A sharp reduction of customs payments. The crisis manifestations in the state's economy and a significant deficit of the national budget have a negative impact on the socio-economic development of the state.

5. Difficulty and burdensome customs procedures. The complex state licensing system and the opaque structure of a state control over export-import operations act as a limiting factor for the development of international trade.

An excessive bureaucracy in the field of foreign economic activity leads to a sharp increase in transaction costs in foreign trade. For example, according to the results of Doing Business 2017, the duration of export operations in Ukraine is 122 hours, and the cost of processing documents for export is USD 367. The situation with import operations is even more complicated. They last about 240 hours and require documents for USD 312 (Zovnishnoekonomichni..., (n.d.)). As a result, transaction costs in Ukraine amount $40 \%$ of the value of foreign trade operations.

In comparison, it should be noted that the average duration of foreign trade operations in most of the EU countries does not exceed 1 hour, and there are no associated excess costs. Thus, high transaction costs in the international trade as a result of ineffective work of the customs authorities, an excessive bureaucratization of the customs clearance procedure, delays in the supply of products abroad or a significant corruption component lead to irreversible losses for the national economy, reducing revenues and international competitiveness of business and increasing costs of customers.

6. A lack of available funding. Interests on export credits, as well as the costs of export insurance in Ukraine are much higher than in the EU. It provides uncompetitive conditions for many Ukrainian producers compared to the European ones. Moreover, there are national state agencies operating in the EU countries that provide preferential conditions for obtaining export credits, insurance and export guarantees - Export Credit Agencies (ECAs). There are, in particular, Euler Hermes in Germany, COFACE in France, and ECGD in the UK. The corresponding 
institutions have been established in Central European and Baltic countries, such as: Czech Republic, Poland, Hungary, Bulgaria, Lithuania, and Estonia.

The role of the ECAs steadily increases in the development of the international trade due to a strong growth in profits of the leading ECAs. Thus, Euler Hermes covers the risk management processes at five continents and has affiliates and representatives in 54 countries. Insurance contracts of credit risks provide delivery of goods and services in 245 countries. The ECAs employ more than 6.000 employees, serving around 52.000 clients. The net profit of the ECAs steadily increases and currently reaches about EUR $500 \mathrm{mln}$ a year, and equity capital - EUR $2.5 \mathrm{bln}$.

Due to the lack of appropriate mechanisms of a state support for insurance and export financing in Ukraine, domestic exporters operate in conditions of the unequal competition in the international markets of goods and services. Due to the limited demand for exports in the domestic market, a supply of goods and services is almost the only means of development of Ukrainian enterprises. Nowadays it is increasingly relevant to create an appropriate institutional and financial support to Ukraine for effective realization of its export potential owing to the launch of the ECAs (Zovnishnoekonomichni..., (n.d.)).

In addition, some difficulties can be attributed (Manaenko, Putilina, 2017), such as: the adaptation and changes in the legal framework require the attraction of funds; crowding out of small and medium enterprises due to the competition; high costs for the production modernization; an increased competitive pressure on certain industries in the domestic market, which could lead to their disappearance; a negative trade balance increased due to the huge exports of raw materials and semi-finished products; the insecurity of new sectors of the economy that do not have the required level of competition.

\section{Conclusions}

The European Union should become a school of the effective innovative economy with high social standards and effective management of social development for Ukraine. Despite numerous problems there are prospects of the foreign trade relations between Ukraine and the EU within the framework of the Association Agreements. In our opinion, the priority directions of such relations are (Fig. 2):

1. Introducing a comprehensive implementation strategy. Ukraine needs the following reforms for the implementation of the European legislation:

- A civil service reform. This basic reform will enable the modernization of the basic instrument (public service) which is necessary to ensure the successful implementation of reforms at the administrative level. Most of reforms will be doomed without it to sabotage by officials.

- A reform of anti-corruption legislation. It is intended to eliminate the conditions and incentives for the implementation of corrupt acts, ensure the inevitability of punishment for committing corruption acts, limiting the impact of private capital on politics.

- A deregulation reform. The dismantling of the old regulatory system inherited from the Soviet times is designed to operate under the command and administrative system. The creation of a new regulatory system meets the essence and needs of a market economy. The realization of this reform will help to improve the investment and business.

- A tax reform. The main emphasis is a significant simplification of a tax administration, the refusal to use a system of advance tax payments, and the reduction of a fiscal pressure on the wage fund (Implementatsiia..., 2015).

The implementation might take a lot of efforts. In order to be fully accepted in the EU, it is necessary to deliver convincing results not only in the economic policy, but in legal aspects, too. It is very urgent for investors to see a reliable government structure and the population's behaviour with the increase in prosperity. 


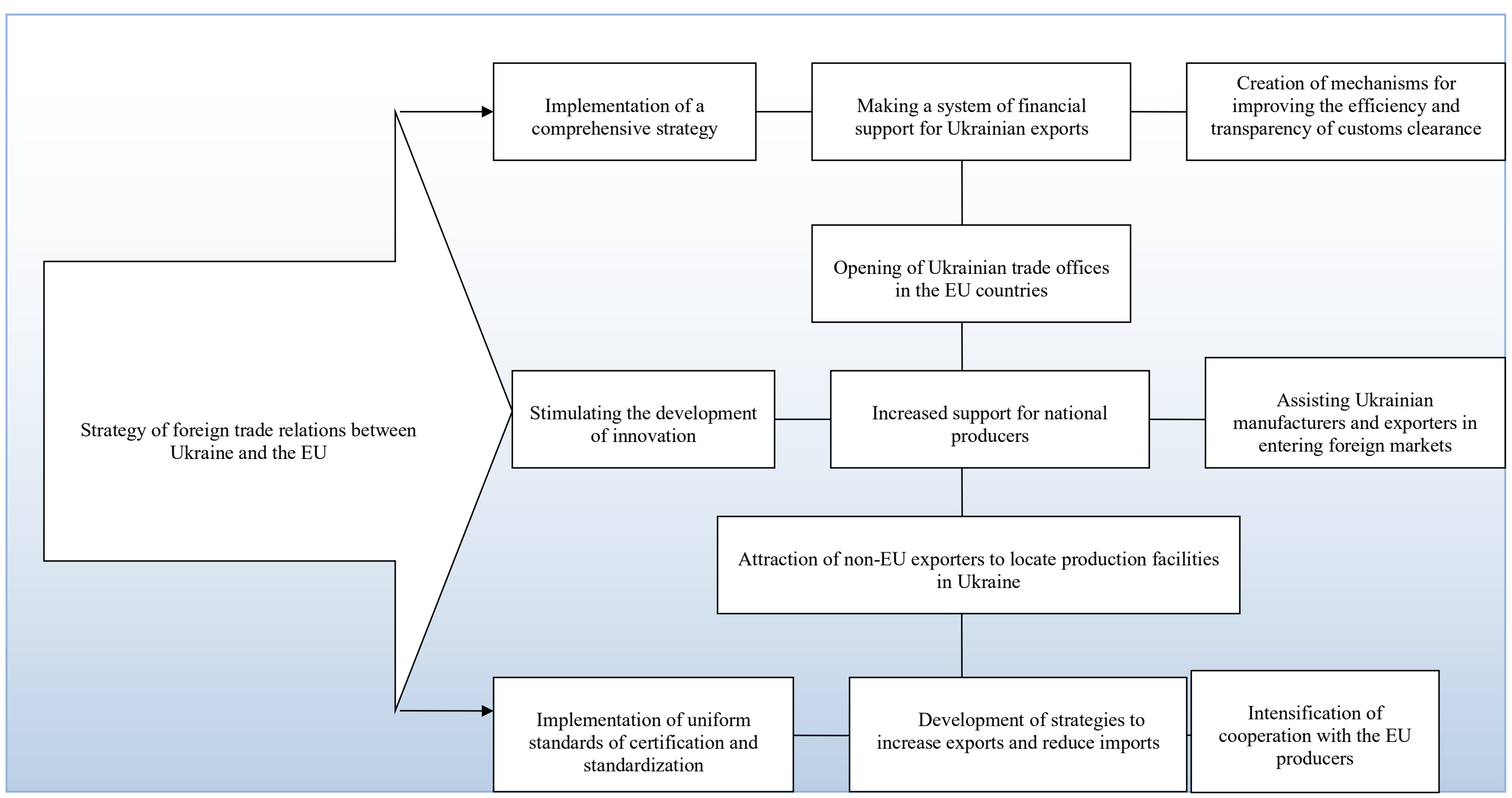

Fig. 2. Strategy of Foreign Trade Relations between Ukraine and the EU

Sources: compiled by the authors 
2. Creating a system of financial support for Ukrainian exports to EU countries, including the launch of ECA's work to secure preferential lending, insurance and guarantee of export supplies to the European markets.

3. Creating mechanisms for increasing the efficiency and transparency of customs clearance and other customs control procedures in accordance with Ukraine's obligations under the WTO Agreement on Trade Facilitation.

4. Opening trade missions of Ukraine in EU countries with the purpose of activating longterm trade and economic relations between Ukrainian and European business representatives.

5. Stimulating the development of innovation in the framework of the implementation of the international programs «Horizon 2020», COSME / EEN and European Grid Infrastructure.

6. Increased support for national producers especially SMEs, in terms of access to EU markets. In this context, the coordinated work of state authorities, local governments and business associations is needed.

7. Ukrainian enterprises need not only a change in the production system but also its modernization, in order to prevent the production of low-quality products. Of course, the domestic consumers only win. On the other hand, the assistance of state authorities to Ukrainian producers and exporters in external markets should become a priority work of the official institutions.

Ukraine should produce ready made goods instead of selling raw materials and semifinished product. The EU has an enormous backlog in the area of IT development. Ukraine should expand its "product portfolio" with IT services. It would be a great challenge and opportunity for Ukrainian software engineers, especially in modern electric cars like TESLA that can be a further development of the country.

8. Attracting exporters from non-EU countries to locate production capacities in Ukraine with further prospects of supplying products to the European markets (Yarosh-Dmitrenko, 2017).

9. Introducing common standards of certification and standardization of products in Ukraine in order to eliminate low-quality imported products from the markets and create the environment of benign competition.

10. Developing and implementing a number of national (regional) strategies to increase the export of national goods and services to EU markets and reducing import supplies to Ukraine.

11. Activating a cooperation with EU producers in transferring production (part or in full) to Ukraine and replacing imported products in national markets for products produced in the country.

Further developments should address in more detail the problems and prospects of Ukraine's cooperation with individual EU member states.

\section{References}

Avramchenko, K., Filipchuk, V., Zholud, O., Maziarchuk, V. (2013). Vplyv stvorennia zony vilnoi torhivli z YeS na ekonomiku Ukrainy: analitychne doslidzhennia. Kyiv: Mizhnarodnyi tsentr perspektyvnykh doslidzhen. p. 197.

Buryak, A. A. (2017). Investytsiine spivrobitnytstvo mizh Ukrainoiu ta YeS u promyslovosti: rehionalnyi rozriz. Naukovyi visnyk Mizhnarodnoho humanitarnoho universytetu. Ekonomika i menedzhment. №25 (2): p. 30-34.

Butyter, D., Wachowska, M. (2015). Foreign Trade and Innovation: Evidence from Ukraine. Journal of International Studies. №8 (1): p. 173-182.

Chauffour, J.-P., Ivanic, M., Laborde, D., Maliszewska, M., Martin, W. (2011). Impact of a Free Trade Agreement between Ukraine and the European Union on Ukraine's Agricultural Sector. - Online access: http://www.gtap.agecon.purdue.edu/resources/res_display.asp?RecordID=3630 [2019 02 12].

Bulakh T. M., Ivashchenko O. A., Plakhotnikova L. O. (2019). Analiz stanu ta tendentsii rozvytku zovnishnoi torhivli Ukrainy z krainamy YeS. Naukovyi visnyk Natsionalnoi akademii statystyky, obliku ta audytu. №1-2: p. 59-68.

Bulakh, T. M., Ivashchenko, O. A., Lytvyn, O. Ye. (2018). The Evaluation of Investment Cooperation of Ukraine with EU Countries. Statystyka Ukrainy. №4: p. 50-56. 
Harbovska, D. (2017). Uhoda pro asotsiatsiiu Ukrainy z YeS: problemy ta perspektyvy realizatsii. Online access: http://www.uzhnu.edu.ua/uk/infocentre/get/16595 [2019 02 12].

Heiler, M., Piatnytskyi, V. (2013). Torhivlia z YeS v ramkakh pohlyblenoi ta vseosiazhnoi uhody pro vilnu torhivliu. Online access: http:meold.kmu.gov.ua $>$ minec/file/link...DCFTA EU_UA.pdf [2019 02 18].

Heyets', V., Shynkaruk, L. (Ed.). (2014). Intehratsiini mozhlyvosti Ukrainy: perspektyvy ta naslidky : naukova dopovid. Kyiv Instytut ekonomiky ta prohnozuvannoa. NAN Ukrainy, p. 92.

Implementatsiia Uhody pro asotsiatsiiu mizh Ukrainoiu ta YeS: torhovelna ta biudzhetnopodatkova sfery. (2015). Online access: http:www.icps.com.ua [2019 03 06].

Lytvyn O. (2016) Zovnishn'otorhovel'na diyal'nist' Ukrayiny $\mathrm{v}$ ramkakh pidpysannya «ZVT+» z krayinamy YES ta ZVT z SND. Aktual'ni problemy mizhnarodnykh vidnosyn: Zbirnyk naukovykh prats'. № 127 (1): p. 116-127.

Lutskiv, O.M. (n.d.). Napriamy vzaiemodii Ukrainy ta YeS v innovatsiinii sferi. Online access: http://ird.gov.ua/irdp/e20150101.pdf [2019 03 01].

Maksak H., Shelest, H., Koval, N., Koval, M. (Ed.). (2017). Ukrainian Prism: Foreign Policy 2016. Analytical study. Kyiv: Foreign Policy Council "Ukrainian Prism". Online access: http://prismua.org/wp-content/uploads/2017/02/Scorecard-2016_eng.pdf [2019 03 01].

Manaienko, I. M., Putilina, D. O. (2017). Tendentsii torhovelno-ekonomichnoi spivpratsi Ukrainy ta YeS. Skhidna Yevropa: ekonomika, biznes ta upravlinnia. №3: p. 10-14.

Nekhay, O., Hubertus Gay, St., Fellmann, Th. (2011). A Free Trade Agreement between Ukraine and the European Union: Challenges and Opportunities for Agricultural Markets. Online access: http://ageconsearch.umn.edu/bitstream/114616/2/Nekhay_Olexandr_70.pdf [2019 03 01].

Oficijnyj sait Ministerstva ekonomichnoho rozvytku i torhivli Ūkrainy. (2017). Online access: http://me.gov.ua/ [2019 03 20].

Official website of the Eurostat. (2017). Online access: http:// ec.europa.eu/eurostat [2019 03 19].

Official website of the State fiscal service. (2017). Online access: http://sfs.gov.ua [2019 03 19].

Poshedin, O., Chulaievska, M. (2017). European Integration of Ukraine: Tool for Internal Reform, Source of Problems or Pass Ticket to EU Membership?. Romanian Journal of European Affairs. №17 (1): p. 100-120.

Potter, M. (2017). International Relations Outside the European Union: Ukraine. Online access: http://www.niassembly.gov.uk/globalassets/documents/raise/publications/2016/2021/2017/ executive_office/0417.pdf [2019 03 15].

Rāboshuk, A., Shymanska K. (2016). Stan i perspektyvy zovnishnoi torhivli mizh Respublikoiu Polshcha ta Ukrainoiu. Vistula University Working Papers. №47 (2): p. 254-268.

Rudik, O. (2014) Uhoda pro asotsiatsiiu z YeS: znachennia dlia Ukrainy. Kazna Ukrainy. №5: $p$. 10-14.

Sibekina, A. Yu. (2018). Derzhavne rehuliuvannia zovnishnotorhovelnoho sektoru na zasadakh pohlyblenoi i vseosiazhnoi zony vilnoi torhivli Ukrainy z YeS. Skhidna Yevropa: ekonomika, biznes ta upravlinnia. №5(16): p. 97-104.

Uhoda pro asotsiatsiiu z Yevropeiskym Soiuzom: novi mozhlyvosti dlia ukrainskoho biznesu. (n.d.). Online access: http://old.eu-ua.org/novi-mozhlyvosti-dlia-biznesu/ [2019 03 14].

Vinokurov, E., Balas, P., Emerson, M., Havlik, P., et al. (2016). Non-Tariff Barriers and Technical Regulations. Online access: http://pure.iiasa.ac.at/id/eprint/13968/1/Nontariff\%20barriers\%20and\%20technical\%20regulations.pdf [2019 03 14].

Vošta, M., Musiyenko, S., Abrhám, J. (2016). Ukraine-EU Deep and Comprehensive Free Trade Area as Part of Eastern Partnership Initiative. Journal of International Studies. №9(3): p. 2135 . 
Wolczuk, K. (2009). Implementation without Coordination: The Impact of EU Conditionality on Ukraine under the European Neighbourhood Policy. Europe-Asia Studies. №61(2): p. 187-211.

Yarosh-Dmytrenko, L.O. (2017) Zovnishnotorhovelni vidnosyny ukrainy z krainamy Yevrosoiuzu u konteksti intehratsii do yevropeiskoho ekonomichnoho prostoru. Naukovyi visnyk Mizhnarodnoho humanitarnoho universytetu. Ekonomika i menedzhment. №25(1): p. 48-52.

Yatsenko, O., Nitsenko, V., Karasova, N., James, H. S. Jr., Parcell, J. L. (2017). Realization of the potential of the Ukraine-EU free trade area in agriculture. Journal of International Studies. №10 (2): p. 258-277.

Zovnishnoekonomichni vidnosyny Ukrainy Z YeS. (n.d.). Online access:

http://forumkyiv.org/uk/analytics/ zovnishnoekonomichni-vidnosini-ukrayini-z-yes [2019 03 04]. 